\title{
Tetrameres (Tetrameres) nouveli bodrogensis n. ssp. (Spirurata) and other nematodes of three species of shorebirds (Charadriiformes) in the Slovak Republic
}

\author{
J.K. MACKO, A. ŠTEFANČÍKOVÁ, A. MACKOVÁ ${ }^{1}$ \\ Parasitological Institute of the Slovak Academy of Sciences, Hlinkova 3, 04001 Košice, Slovak Republic, \\ E-mail: astefan@saske.sk; ${ }^{1}$ Institute of Science, P. J. Šafárik University, Mánesova 23, 04154 Košice, Slovak \\ Republic; E-mail: amacko@kosice.upjs.sk
}

\begin{abstract}
Summary
Eight taxons of nematode parasites were recovered from three species of charadriid shorebirds (Charadriiformes) from Slovakia: common ringed plover - Charadrius hiaticula (L.) $(\mathrm{No}=9)$, little ringed plover - Charadrius dubius Scop., $1786\left(\mathrm{No}^{-}=56\right)$ and golden plover - Pluvialis apricaria $(\mathrm{L}).(\mathrm{No}=14)$. New host record $(C h$.dubius $)$ were registered for Tetrameres (Tetrameres) nouveli (Seurat, 1914), described as so far unknown Tetrameres (T.) nouveli bodrogensis n. ssp. New data on Victorocara charadrii Belopolskaja, 1953 have been pointed out. Besides the taxons mentioned above, the following species were registered: Eucoleus contorta, Eucoleus obtusiuscula and in Slovakia so far not described Capillaria limicolae, Tetrameres (T.) sp., Capillaridae gen. sp. and Anisakidae gen. sp.
\end{abstract}

Key words: Nematoda; Tetrameres (T.) nouveli bodrogensis n. ssp.; Victorocara charadrii; Charadriiformes; Charadrius dubius; Charadrius hiaticula; Pluvialis apricaria; Slovak Republic

\section{Introduction}

Nematodes of common ringed plover - Charadrius hiaticula (L., 1758) little ringed plover - Charadrius dubius Scop., 1786 and golden plover - Pluvialis apricaria (L., 1758) belong to the group of not researched helminths in Slovakia. The mentioned hosts are members of our avifauna, in particular during their migration time (Ferianc, 1977), when the research of their parasites has been carried out. The presented study follows up the data on plathelminthes of shorebirds by Macko et al. (2004), Hanzelová et al. (in press.), containing also information about recent studies of parasites of Charadriiformes in other distribution areas. In former Czechoslovakia, the revisions of registered nematodes were done in particular by Moravec (1982), Baruš (1964), or Baruš and Sergejeva (1989a,b). The findings of nematodes in plovers from the 50's and 60's in Slovakia are not only of historical importance, but they have contributed to the understanding of the species composition and abundance as well as to specification of their morphology.

\section{Material and Methods}

A total of 79 shorebirds were collected from the localities of Eastern and south-western Slovakia in 1957 - 1969. Out of them 38 investigated bird hosts originated from Senné wetland, which has recently been designated as an internationally significant "Ramsar locality" in Slovakia. Other birds were obtained from the localities of water gates on the Topl'a River near Bardejov, Domaša, Stropkov, Moča and others. As many as 9 specimens of Charadrius hiaticula, 56 specimens of Ch. dubius and 14 individuals of Pluvialis apricaria were examined. Nematodes were fixed and conserved in Barbagallo solution. The males of the genus Tetrameres were mounted into liquido faure (Hovorka, 1954). Due to the fact that they had been in this medium for more than 35 years, the nematodes had to be demounted and separately examined in lactic acid. Then they were mounted into $4 \%$ glycerol formol as "liquid" permanent slides. The helminths are deposited at the Parasitological Institute SAS in Košice. Measurements are in micrometers $(\mu \mathrm{m})$, unless otherwise stated.

\section{Results}

\section{Nematoda}

Tetrameres (Tetrameres) nouveli bodrogensis $\mathrm{n}$. ssp.

(Plate I., Figs 1 - 7, Plate II., Figs 1 - 4)

Type host: Charadrius dubius Scop.,1786

Type locality: Senné (East Slovakia)

Other localities: Domaša, Stropkov

Site of infection: Proventriculus 


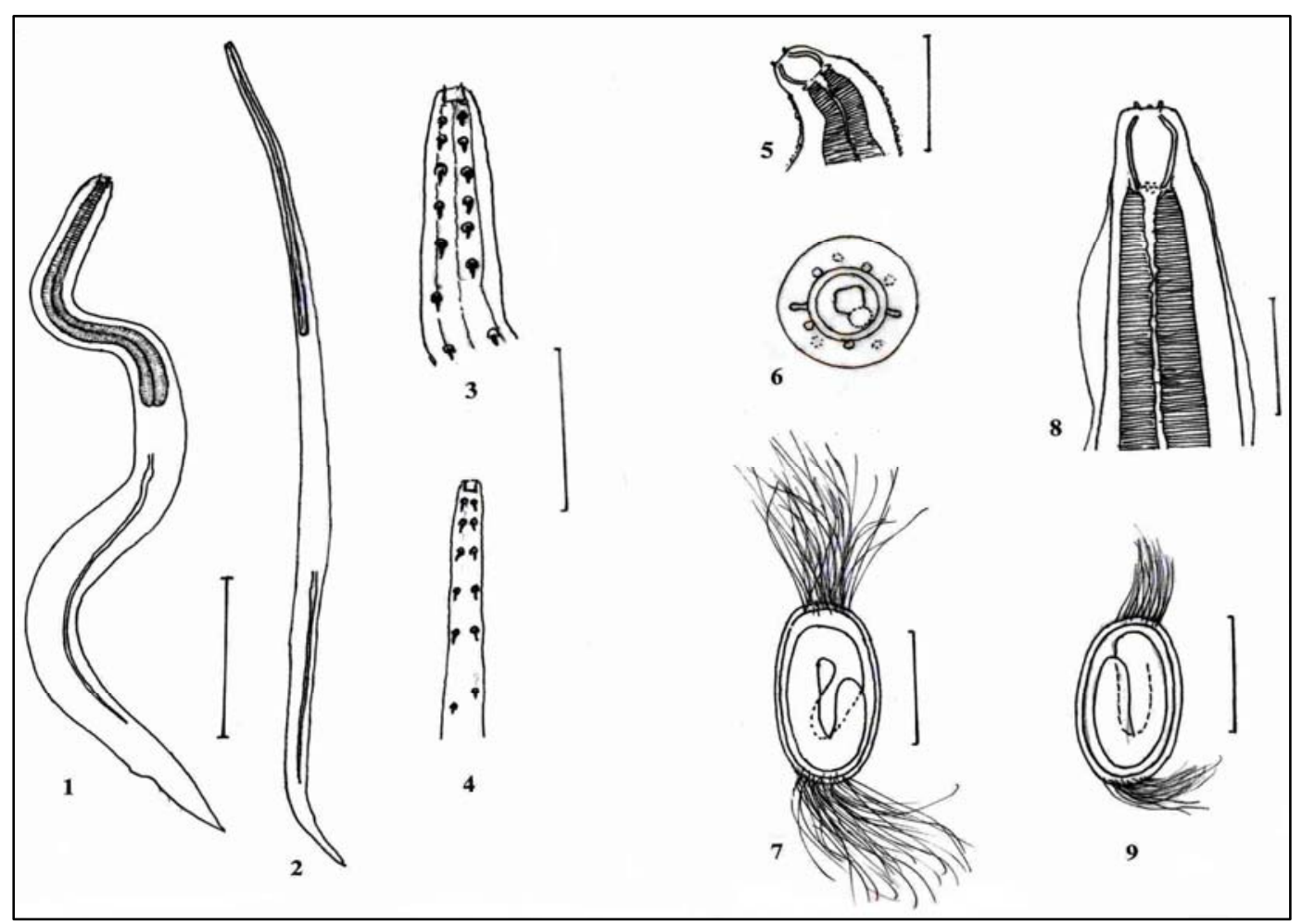

Plate I. Tetrameres spp.

1 - 7. Tetrameres (T.) nouveli bodrogensis $\mathrm{n}$. ssp. from Ch. dubius. 1 - 2. Variability of males, general view, spines ommitted. Bar. $200 \mu \mathrm{m} .3-4$. Variability of anterior end of males. Bar $100 \mu \mathrm{m}$. 5. Anterior end of female. Bar $30 \mu \mathrm{m}$. 6. Apical view of female - sketch 7. Egg. Bar $30 \mu \mathrm{m} .8-$ 9. Tetrameres (T.) sp. from Pluvialis apricaria 8. Anterior end of female. Bar $30 \mu \mathrm{m}$. 9. Egg. Bar $30 \mu \mathrm{m}$.

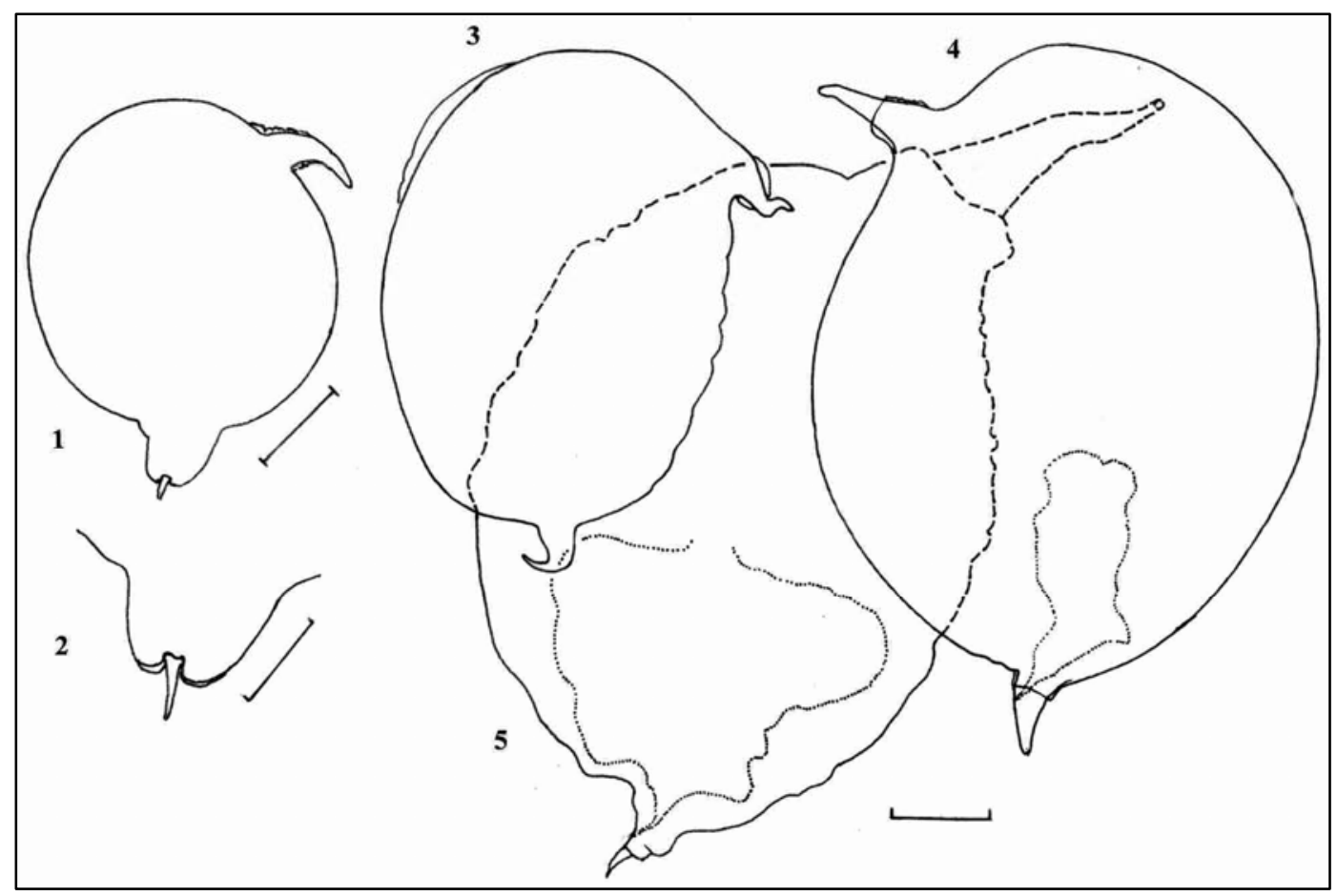

Plate II. Tetrameres spp.

1,3,4. Tetrameres (T.) nouveli bodrogensis $\mathrm{n}$. ssp. from Ch. dubius. Females various size and shapes. Bar $200 \mu \mathrm{m}$. 2. Tetrameres (T.) nouveli bodrogensis $\mathrm{n}$. ssp. Posterior end from fig. 1. Bar $100 \mu \mathrm{m}$. 5. Tetrameres (T.) sp. from Pluvialis apricaria. Comparative size of female Tetrameres (T.) sp. with females of $T$. (T.) nouveli bodrogensis $\mathrm{n}$. ssp. fig. 1, 3, 4 . 
Prevalence: $9 / 56$ i.e. $16 \%$

Intensity of infection: $1-14$ specimens

Etymology: New subspecies was named on base river basin Bodrog on East Slovakia.

Males (based on 8 specimens). Body length $826-1190$. Maximum width $31-59$ in anterior part of the spicule (Pl.I/1, 2). Lateral alae unclear, even doubtful. Mouth surrounded by feebly developed lateral pseudolabia. Buccal cavity $6-8 \times 5-10$. A total oesophagus length $335-370$. Maximum width $24-31$ in the posterior part. Neither nerve ring, nor margin between muscular and glandular oesophagus was reliably identified. Cuticular spines in four longitudinal rows. Spines with disc-like bases $7-10$ long. In some males, spines are arranged in $2-5$ distances, in another in $17-25$ or more $(\mathrm{P} 1 . \mathrm{I} / 3,4)$. In central part of the body the distance between spines in longitudinal rows grows, while spine length is reduced on $3-4$. In middle of the body of some cases spines missing. In area of cloacal opening

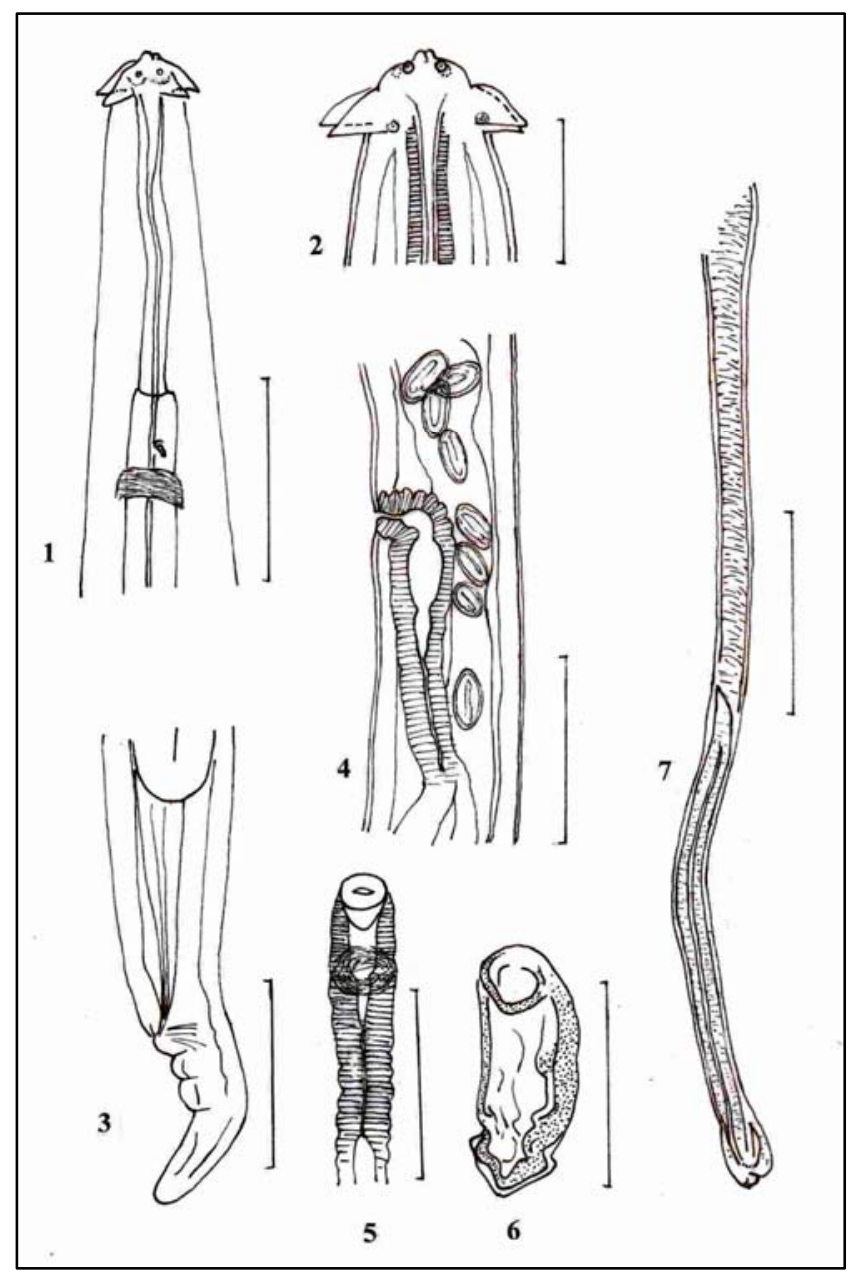

Plate III. Victorocara charadrii Belopolskaja, 1953 from Ch. hiaticula

1.Anterior end of female.Bar. $100 \mu \mathrm{m}$. 2. Lateral views of females head. Bar $30 \mu \mathrm{m}$.

3. Posterior end of female. Bar $200 \mu \mathrm{m}$. 4.Vulvar region. Bar 200 $\mu \mathrm{m}$. 5. Vulvar opening, ventral views. Bar $200 \mu \mathrm{m} .6-7$. Spicules of male. Bar $100 \mu \mathrm{m}$. spines 5 - 7 long. A single spiculum (260) 303 - 406 long. The males with spiculum 260 long regarded as juvenile (P1.I/2). Proximal part of spiculum $27-31$, maximum width up to 7 . In middle part, width of spiculum $3-4$. Cloacal opening situated on $79-123$ from the body end. Behind this opening are $3-5$ pairs of ventrolateral spines. The postcloacal spines are unvisible. Visible papillae were not observed.

Females (based on 7 specimens). Gravid females $1100-$ 1687 long, 880 - 1537 width. Forepart of the body include muscular oesophagus and a part of glandular oesophagus $140-312$ x $125-188$. The mouth surrounded by an inconspicuous circumoral membrane with unclear several pairs of cephalic papillae and 2 amphides (Pl. I./6). Buccal capsule $11-15$ long and $9-12$ wide. Muscular oesophagus $115-136 \times 27-38$. Whole oesophagus $663-740$ x $60-72$. Nerve ring $66-72$ from an anterior end. Posterior extremity is with maximum length $94-204$, and maximum width $55-165$. Vulva inconspicuous located approximately 187 and anus $74-100$ from posterior end. Eggs with developed larvae $39-50 \times 21-28$ with a bundle of $30-40$ polar filaments up to 55 long. In older material filaments probably shatter rather quickly, as they were detected only in a small number of eggs after their releasing from uterus. The egg wall $2-3$ thick. (P1.I./7).

Subspecies-holotype: Males permanent preparation No. 269/65b. Size 918 x 48. Buccal capsule 7 x 10. The postbuccal spines 7 , postcloacal $5-6$ long. The whole oesophagus is $335 \times 24$. Spiculum 369 long, in mid part 7 wide. The cloacal opening 88 from posterior part of the body (P1.I./1). Suitable allotype of subsp. from No.269/65 not available.

Comments: Great metrical and morphological variability of subsp. $\mathrm{n}$. has probably been caused also by change of nematode generations in hosts in April and May in the Slovak areas (Macko \& Birová, 1969, 1976; Birová \& Macko, 1976). This phenomenon is connected with the change of individuals, representing specific phenotype composition, adapted on different environmental conditions, i.g. at nesting and wintering sites of birds (cfr. Špakulová \& Mutafová, 1987).

\section{Discussion}

Original description of Tropidocerca nouveli Seurat, 1914 was formed based on isolated nematodes from the host $\mathrm{Hi}$ mantopus himantopus in Algeria (Skryabin and Sobolev, 1963). Another forms of this species were registered from various Charadriiformes in the former USSR by Borgarenko (1965, ex Mollhagen 1976), in Australia by Mawson (1968), in Cuba by Baruš and L. Hernandez (1971), Otero and.L. Hernandez (1982) and in the USA by Mollhagen (1976). According to Mollhagen (1.c.) and the data of cited authors, the parameters of the $T$. nouveli* males were as follows: length $1.0-2.40 \mathrm{~mm}$, anterior spines $15-17$. Tail 98 - 140. Variable number of caudal papillae. Buccal capsule $7-10 \times 8-10$. A total length of oesophagus $420-$ 787. Left spiculum $312-587$. Right one absent or rudi- 
mentary -28 long. Eggs embryonated, thick shelled $50-$ $55 \times 26-30$ with $6-8$ polar filaments $70-117$ long. (Only the most important parameters have been selected).

It is not possible to unambiguously classify our tetramerids in any of the species, or a host from the genus of Tetrameres. On the other hand, several overlaping morphological features of our specimens with other taxons $T$. (T.) nouveli Seurat (1914), T. (T.) paraaraliensis Oschmarin, 1965; T. prozeskyi (Ortlepp, 1964)* do not refer to a new species.

$T$. (T.) nouveli bodrogensis $\mathrm{n}$. ssp. differs from the male of Seurat's form by smaller measurements of body, organs, spicules and shape of their anchorage. Besides that also by the length of left spicule (in our form 260 - 406 in contrast to 480 ). Seurat also mentiones an atrophied right spicule and gubernaculum.

New subspecies differs form the host form of T. nouveli* from Ch. alexandrinus from Australia (Mawson 1968) by:

1.) smaller cuticular anterior spines $7-10$ in comparison to 15 - 17 (Mollhagen, 1976).

2.) disc-like anchoring of cuticular spiculae - unlike illdefined basis in $T$. (T.) nouveli.

3.) eggs with developed larva and a bundle of 30 or 40 polar filaments up to 55 long in comparison to $6-8$ polar filaments $70-117$ long listed for T. nouveli*

Described new subspecies is similar in particular to $T$. (T.) paraaraliensis Oschmarin, 1956 sensu Jögis (1974)* from hosts Charadrius hiaticula and Ch. dubius. Males 1.1-1.3 x $0.05-0.06 \mathrm{~mm}$. Anterior cuticular spines 12 long. Buccal capsula $8 \times 8$. Spicule $310-380$. In tree males, a slightly sclerotised formation a $10-18$ long rudiment of the second spicule was found. Females were not described. The original male form $T$. (T.) paraaraliensis described by Oschmarin from Vanellus vanellus (Skryabin and Sobolev, 1963), diferring from T. (T.) nouveli bodrogensis n. ssp. in: 1.) Body size. 2.) Spicule length 420, in our tetrameres 260 - 406. 3.) In females. Oschmarin examined only immature female with no eggs. Without their description it is not possible to classify our tetramerids into $T$. (T.) paraaraliensis. In case of these forms being "identical", several authors would considered

Oschmarin's species as synonymum of $T$. (T.) nouveli. (cfr.Mollhagen, 1976). *author did not use three nominal nomenclature

The spiculum of our one male of $T$. (T.) nouveli bodrogensis n. ssp. (260) overlaps with the spiculum of T. prozeskyi*, its left one long $230-260$. Around $10 \%$ of males have two spiculae. Right one measuring $190-220$. Eggs oval and morulated without filaments (Ortlepp, 1964).

Tetrameres (T.) sp.

(Plate I., Fig. 8 - 9; Plate II., fig. 5)

Host: Pluvialis apricaria (L, 1758.)

Locality: Senné

Site of infection: Proventriculus

Prevalence: $1 / 14$, i.e. $7.1 \%$

Intensity of infection: 3 specimens(females)

Male: unknown
Females (based on 3 specimens). Gravid females: length 2150 - 2482, width 1275 - 1320. Forepart of body $487-$ 731 long. Buccal capsule $18-20 \times 12-15$ (Pl. I./8). Muscular oeasophagus $256-271 \times 27-33$. Nerve ring $130-$ 165 from anterior body end. Glandular oesophagus $745-$ 772. Anus $94-105$ from posterior body end. Eggs with larvae $41-45$ x $25-27$ (P1.I./9). Only in small number of eggs, the bundle of $15-20$ filaments, length of $15-20$ was preserved on the poles.

Comments: Affiliation of Tetrameres (T.) sp. to above mentioned form is rather doubtful due to larger buccal capsule, small number of shorter filaments on the egg poles. The females of $T$. (T.) nouveli bodrogensis n. ssp. and Tetrameres (T.) sp. often have at fore and hind body a pouch-like margins, suggesting that the anterior and posterior extremity may to a certain extent protrude ( Pl. II./1,2,4,5). One female of T.(T.) nouveli* bodrogensis n. ssp. was found with such a short extremity that without brightening they were almost invisible.

Victorocara charadrii Belopolskaja, 1953

(Plate III., Figs $1-7$ )

Host: Charadrius hiaticula (L., 1758)

Locality: Senné

Site of infection: beneath cuticle of muscular stomach

Prevalence 1/9 i.e.11.1\%

Intensity of infection: 10 specimens

Body often in spiral shape. Anterior end with eight cephalic papillae, two pseudolabia and four lateral cuticular projections.

Males (based on 3 specimens). Body length $6.3-7.3 \mathrm{~mm}$. Maximum body width $7-101$. Cuticular projections on the anterior end, $12-13$ long. Vestibule $124-142 \times 7-9$. Muscular part of oesophagus $421-499 \times 21-23$ and glandular part $889-1116$ × 31 - 45 long. Cone-like cervical papillae situated in anterior part of muscular oesophagus in the distance of $171-173$ from anterior end of the body. Nerve ring (width of 14), 172 - 175 from anterior end. The spiral male tail with relatively narrow caudal alae. Cloaca opening 121 from posterior end of body. Five pairs of preanal papillae observed. The sixth pair on the deformed material unclear. Five pairs of postanal papillae present. Left spiculum $452-486$ long at proximal end with cone-like widening, 31 wide. Other parts of long spicule width of 15 . The short right spiculum bowle-shaped $120-$ 135 x 26 ( P1.III./6,7).

Mature females (based on 5 specimens). Body length 13087 - 18150. Maximum body width $120-179$. The length of cephalic cuticular projections $13-14$ (Pl. III./1,2). Vestibule $138-158 \times 10-14$. Muscular part of oesophagus $499-585 \times 25-31$ and glandular part $1057-$ 1305 x 46 - 59 long. Cone-like cervical papillae $181-200$ from anterior end of the body. Sometimes one papilla situated lower than the other. Nerve ring (width 28) 193 210 from anterior end. Slit-shaped vulva in the posterior part of body $9300-10238$ from anterior end (PL. III./4-5). Anus $164-179$ from posterior body end. Mature eggs $45-52$ × $26-28$ contain a larva. 
Comments: Our nematodes differ from the original description of $V$. charadrii in some body and organs measurements and mainly in position of cervical papillae. Cfr. Belopolskaya (1953, Fig.7a) and Skryabin et al. (1965). Further species V. schejkini Guschanskaja, 1950; V. guschanscoi Leonov, 1958 and V. limosae Mawson (1968) differ in particular in spiculae measurements or length of cuticular projections at the head end and some organs measurements. (Table 1). The studied females of $V$. guschanscoi were according to Leonov (in Skryabin et al., 1965) immature, as their uterus did not contain completely formed eggs. Mature females were described by Macko and Baruš (1973).

Our findings contribute to the knowledge on organs measurements of mature $V$. charadrii and on occurrence of the species in Slovakia during Ch. hiaticula migration.

Eucoleus contortus (Creplin, 1839)

Host: Charadrius hiaticula (L., 1758)

Site of infection: oesophagus

Locality: Senné

Prevalence: $1 / 9$, i.e $11.1 \%$

Intensity of infection: 3 specimens (females)

Parasitising in aquatic poultry and in many species of aquatic birds, or such birds which are vicinity living to the water. The obtained capillariids are not fully grown, however, their uterus contains relatively large eggs $62-72 \times 27$ - 31. Baruš and Sergejeva (1989b) report 55 - 67 x $22-$
27.

Eucoleus obtusiuscula (Rudolphi, 1819)

(Plate IV., Fig. 1-10)

Host: Charadrius dubius Scop., 1786

Locality: Senné, Domaša, Stropkov, the Topl'a River near Bardejov

Site of infection: beneath cuticle of the muscular stomach Prevalence: $8 / 56$, i.e. $14.2 \%$

Intensity of infection: $2-15$ specimens

Male (based on 5 specimens). Body length $6.8-8 \mathrm{~mm}$, maximal body width $51-55$. Three bacillary bands observed. Oesophagus including stichosome $2405-2562$ long. Length of oesophagus to body length ratio is $1: 2.6-$ 2.96. Stichocytes in one row, $29-34$ in number. At stichosome end measuring $76-86 \times 29$. Spiculum indistinct 320 - 340 long, in medium part $3.5-4.5$ wide, towards the end narrowed to more or less pointed end. Spicular sheath 310. Spines of proximal part of sheat thick short and relatively sparsely spread. Towards the distal end more dense and longer. Distal end of everted sheath armed with elongated, thin, bristle-like spines $8-10$ long. Posterior end of the male with pseudobursa, $26-28$ in average forms two lobes each with a papilla (PL., IV./1).

Female (based on 9 specimens). Body length $16.5-20.2$ $\mathrm{mm}$. Width of body in vulva region $72-76$, maximal body width $95-121 \mathrm{~mm}$. Oesophagus including stichosome $2812-3376$ long. The ratio of oesophageal part to female length $1: 5.88-5.96$. Stichocytes 33 to 35 in number at a

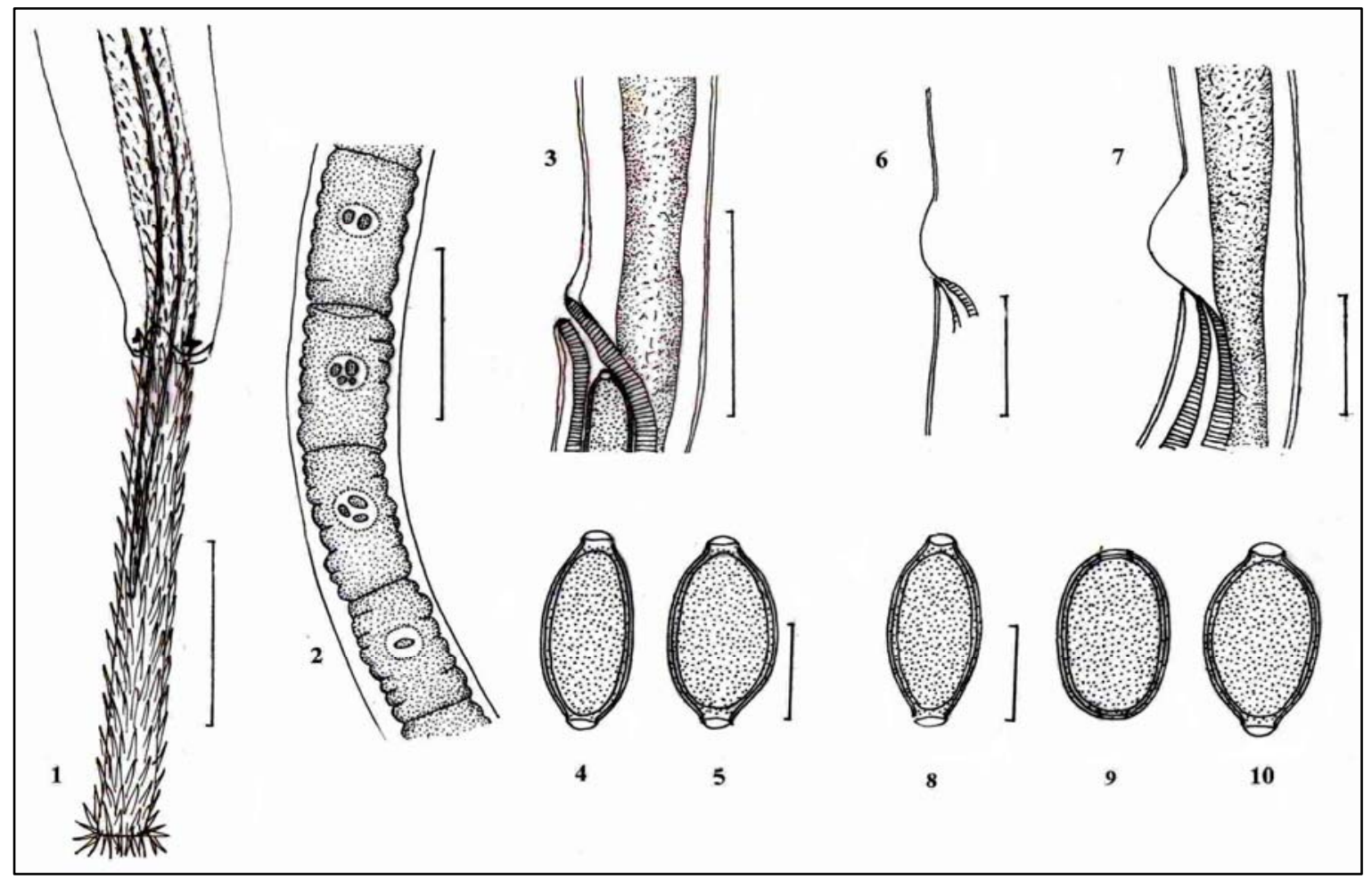

Plate IV. Eucoleus obtusiuscula (Rud., 1918) from Ch. dubius

1. Posterior end of male. Bar $50 \mu \mathrm{m}$. 2. Stichocytes. Bar $100 \mu \mathrm{m}$. 3. Vulva region. Bar $100 \mu \mathrm{m} .4-5$. Eggs. Bar 25 $\mu \mathrm{m}$. 6-7. Vulvar region of atypical form. Bar $50 \mu \mathrm{m}$. 8-10. Eggs of atypical form. Bar $25 \mu \mathrm{m}$. 
Tab. 1 A comparison of closely related males of Victorocara spp.

\begin{tabular}{|c|c|c|c|c|c|}
\hline Nematode species & V. charadrii Belopolskaja, & V.charadrii & V.schejkini & \multicolumn{2}{|c|}{ V.guschanscoi Leonov, V.limosae } \\
\hline & 1953 & Belopolskaja, 1953 & Guschanskaja, 1950 & 1958 & Mawson, 1968 \\
\hline Host & Ch. hiaticula & Ch. hiaticula & Terekia cinerea & $\begin{array}{c}\text { Sterna sandvicensis, } \\
\text { Hydroprogne }\end{array}$ & $\begin{array}{l}\text { Limosa } \\
\text { lapponica }\end{array}$ \\
\hline Region & Senné-Eastern Slovakia & Eastern Murman & Komi (former) USSR & $\begin{array}{c}\text { Tschegrava } \\
\text { (former)USSR }\end{array}$ & $\begin{array}{l}\text { Queensland } \\
\text { (Australia) }\end{array}$ \\
\hline Source of data & Present results & $\begin{array}{c}\text { Belopolskaja } \\
\text { (1953) }\end{array}$ & $\begin{array}{l}\text { ex Skryabin et al. } \\
(1965)\end{array}$ & $\begin{array}{c}\text { ex Skryabin et al. } \\
\text { (1965) }\end{array}$ & $\begin{array}{c}\text { Mawson } \\
(1968)\end{array}$ \\
\hline Total length (L) & $6300-300$ & $5300-5500$ & $5943-6006$ & 6240 & $6500-10200$ \\
\hline Max. width & $79-101$ & 110 at gland. oes. & & 93 & \\
\hline $\begin{array}{l}\text { Length of cephalic } \\
\text { cuticular projections }\end{array}$ & $12-13$ & & 17.4 & 22 & \\
\hline Length of vestibule & $124-142 \times 7-9$ & 110 & $104-109$ & 93 & $130-160$ \\
\hline Cervical papillae & $\begin{array}{c}171 \text { - } 173 \text { from } \\
\text { ant.end }\end{array}$ & $\begin{array}{l}660 \text { from ant. } \\
\text { end }\end{array}$ & $144-152$ & & \\
\hline Nerve ring & $\begin{array}{c}172-175 \text { from ant. } \\
\text { end }\end{array}$ & & & & $\begin{array}{c}180-230 \\
\text { from ant. end }\end{array}$ \\
\hline L. musc. oesophagus & $421-499 \times 21-23$ & 270 & $470-483$ & $496 \times 18$ & $650-820$ \\
\hline L.gland. oesophagus. & $889-1116 \times 31-45$ & -830 & $880-987$ & $1736 \times 55$ & $1600-1800$ \\
\hline Cloaca (Anus) & 121 from posterior end & & 83 from post. end & & \\
\hline Preanal papillae & Confused min. 5 pairs & 6 pairs & 6 pairs & 6 pairs & \\
\hline Postanal papillae & 5 pairs & 5 pairs & 5 pairs & 5 pairs & \\
\hline Left large spicule & $452-486 \times 15-31$ & $470 \times 25$ & $326-348$ & 496 & $760-780$ \\
\hline Right small spicule & $120-134.5 \times 26$ & 102 & $83-87$ & 124 & 150 \\
\hline
\end{tabular}

* Measurements are in micrometers

level of stichosome end with measurements $93-121 \times 50$ - 69. Slotted vulva, slightly exceeding ventral body surface, is situated $117-280$ behind oesophagus (Pl. IV/3). Vagina muscular $600-722$ long. Thin wall eggs with granules measured from Ch. dubius $62-69 \times 24-26$ (P1. IV/4-5), from Ch. hiaticula $74-76 \times 24-28$. The anus is situated terminally.

Atypical form: From the host $C h$. dubius examined 7 females $20.1-22.8$ long were found beneath the cuticle of muscular stomach. Oesophagus including stichosome is $3792-3950$ long. The vulva takes the form of a transverse slit, or the anterior lip of vulva is raised $5-16 \mathrm{~mm}$ above the surface of borders (P1.IV/6-7). Vagina 605 - 928 long. The thin wall eggs of female with the largest anterior vulvar lip $48-62$ × $24-30$. Majority of eggs are without typical plugs in the poles. Only a few eggs were found with typical capillarid form. Surface of eggs is as in form standard (PL.IV/8-10).

Comments: Owing to unstable dimension of anterior lip of vulva we classify this "atypical" form as E. obtusiuscula, even though the mentioned structure of vulva has not been described in this species. The eggs without polar plugs are considered as abnormalities.

"Our" E. obtusiuscula differed more from those reported by Baruš and Segejeva (1989b) in measurement of stichosome in males. According to these authors, E. obtusiuscula has also been recorded in Anas querquedula.

Capillaria limicolae (Gubajev et Mamajev, 1964) 182
Host: Pluvialis apricaria (L., 1758)

Locality: Senné

Site of infection: small intestine (probably duodenum)

Prevalence: $1 / 14$ i.e. $7.1 \%$

Intensity of infection: 3 specimens (females)

Comments: In Charadriformes in Palearctic region the following nematodes of the genus Capillaria (Zeder, 1800) were registered: Capillaria anatis Schrank, 1790 and $C$. limicolae Gubajev and Mamajev, 1964. As for taxonomic features of capillarids, the structure of egg shells was important. In $C$. limicole the membrane in our eggs is thin $1-$ 2 and its surface is strewn with small granules. In C. anatis this membrane is 4 thick and the surface shows irregular pits (Baruš \& Sergejeva, 1989a) So far, this species has not been registered in Slovakia.

Capillariidae gen. sp.

(PlateV., Figs 1, 2)

Host: Charadrius dubius Scop., 1786

Site of infection: beneath cuticle of muscular stomach

Locality: Senné

Prevalence: $1 / 56$, i.e. $1.7 \%$

Intensity of infection: 2 specimens ( 1 male, 1 female)

Male: 8.5 long. Maximum body width 86 . Oesophagus inclusive stichosome 2962 long. Stichocytes at the level of stichosome end $117-124$ x 38. Spiculum 164 x $2-3$. Seventy nine micrometers from the anterior spiculum end situated a small bulbous part (abnormality?) (Pl. V/1). Spicular sheath $185 \times 12$. Its armament has not been observed. 


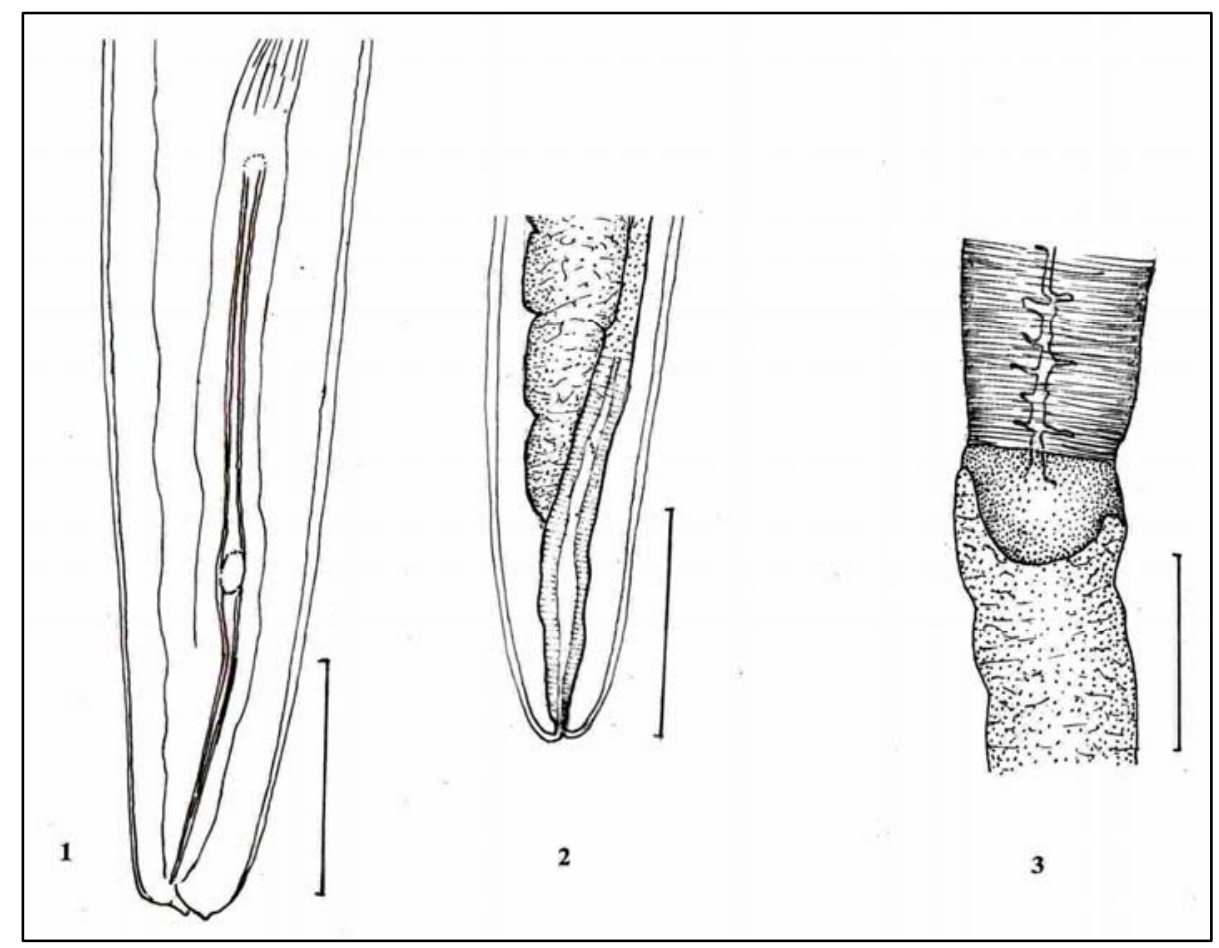

Plate V. Nematoda spp. from Ch. dubius

$1-2$ Capillariidae gen. sp. Posterior end of male. Bar $50 \mu \mathrm{m} .2$ Posterior end of female. Bar $100 \mu \mathrm{m}$. fig. 3 Anisakidae gen. sp. The area of the „tiny stomach“ Bar $200 \mu \mathrm{m}$

Female: Stichocytes $74-119$ x 42 Thin walled eggs $51-$ 57 x $24-26$. Anus terminal.

Anisakidae gen. sp.

(Plate V., Fig. 3)

Host: Charadrius dubius Scop., 1786

Locality: Senné

Site of infection: sediment of body cavity

Prevalence: $1 / 56$ i.e. $1.8 \%$

Intensity of infection: 11 specimens

Developmental forms of nematodes, only one male 16.3 $\mathrm{mm} \times 644 \mu \mathrm{m}$. Anterior and posterior end with cuticular alae. Organs incompletely developed. The form of oesophagus linked with intestine via "tiny stomach" a typical (Pl. V.,/3). Tail end possesss four preanal and $2-3$ postanal pedunculated papilae. Following four? preanal papilae without peduncles. Other nematodes are shorter, different in stage of ecdysis.

The members of the genus Porrocaeum Raillet and Henry, 1912 (Mozgovoy, 1953) are registered in studied hosts.

\section{Conclusion}

The identification of Tetrameres (T.) nouveli bodrogensis n. ssp. showed that $T$. (T.) nouveli Seurat, 1914 has been registered in various species of Charadriiformes on all continents and displays greater host-geographic variability (Mawson, 1968; Mollhagen, 1976) as it is reported in other description of the species of the genus (Skryabin and Sobo- lev, 1963; Ortlepp, 1964; Mawson, 1968; Pence et al., 1975; Digiani \& Cremonte, 2001; Cremonte et al., 2001 and others).

With regards to the above we suggest:

1.) To revise original Seurat's material or at least redescribe $T$. (T.) nouveli on the basis of new material from type host Himantopus himantopus from Algeria. If the revision clarifies Seurat's disputable morphological data and if the hypothesis on great variability of $T$. (T.) nouveli is confirmed, then its subspecies classification (sensu Mayr, 1963) is justified. This taxonomy facilitates the fact that $T$. (T.) nouveli belongs to the species with heteroxenous life cycle (cfr. Chabaud and Bain, 1994) - as example can serve Tetrameres (Petrowimeres) crami asiatica (Ryjikov, 1963 in Skryabin and Sobolev, 1963). Disadvantage is in this case the quadrinominal nomenclature.

2.) Besides other features in various tetramerid species to pay a greater attention to egg morphology in relation to presence of their filaments, their number and length. With regards to the rapid loss of filaments it is highly probable, that eggs of more species are covered with these structures than it has been reported in literature.

Apart from that we have found the following:

3.) Tetrameres (T.) nouveli Seurat, 1914 parasitising in $C h$. dubius described as unknown T.(T.) nouveli bodrogensis $\mathrm{n}$. ssp.; Tetrameres (T.) sp. Victorocara charadrii Belopolskaja, 1953; Capillaria limicolae; Capillaria gen. sp. and Anisakidae gen. sp., were for the first time registered in Slovakia. 
4.) It has been shown that nematode fauna of three shorebirds species is poorer than plathelmintes fauna (Macko et al., 2004). Similar findings result also from the studies of Bondarenko and Kontrimavichus (1999), Canaris and Kinsella (2001) and Canaris et al. (2003).

5.) Common nematode species in studied shorebirds and aquatic poultry is Eucoleus contorta. E. obtusiuscula were detected besides that in Charadriformes also in a duck Anas querquedula (Baruš and Sergejeva, 1989 b).

\section{Acknowledgements}

The authors are indebted to Prof. J. M. Kinsella, University of Florida U.S.A. and to Prof V. Baruš DrSc., Czech Academy of Sciences, Brno for kind providing of relevant literature. This study was supported by the grant of the Scientific Grant Agensy of the Slovak Republic (VEGA), project No. 2/3213/23 and No. 2/4177/04.

\section{References}

BARUŠ, V. (1964): The species of Capillaria Zeder, 1800 and Thominx Dujardin, 1845 (Nematoda, Trichocephaloidea) in Strigiformes and Falconiformes (Aves) in Czechoslovakia. Ćs. Parasitol. (Praha), 11: $51-64$

BARUŠ, V., LORENZO HERNANDEZ, N. (1971): Nemátodos parásitos en aves de Cuba. Parte IV. Poeyana, 88: 1 - 15

BARUŠ, V., SERGEJEVA, T. P. (1989a): Capillariids parasitic in birds in the palearctic region (1) Genus Capillaria. Acta Sc. Nat. Brno, 23: $1-50$

BAruŠ, V., Sergejeva, T. P. (1989b): Capillariids parasitic in birds in the palearctic region (2) Genera Eucoleus and Echinocoleus. Acta Sc. Nat. Brno, 23: $1-47$

BELOPOLSKAYA, M. M. (1953): Helminth fauna of shorebirds in SSSR. In Raboty po gel'mintologii k 75 - letiju. Akad K.I. Skrjabina. Izd. AN SSSR, Moskva, (in Russian) BIROVÁ, V, MACKO, J.K. (1976): Über die lebensfähigkeit und das Überleben der kurzschwänzigen, verkürztschwänzigen und normalschwänzigen Formen, von Heterakis gallinarum. Biológia (Bratislava), 31: 583 - 593

BondarenKo, S.K., Kontrimavichus, V. I. (1999): The helminth fauna of Charadriformes in Alaska: Zoogeographical features and origin. Zool. J., 78: $643-653$

CANARIS, A. G., Kinsella, J. M. (2001): Helminth parasites in six species of shorebirds (Charadrii) from the coast of Belize. Mem. Inst. Oswaldo Cruz, Rio de Janeiro, 96: $827-830$

Canaris, A.G., Kinsella, J.M., Brady, R. (2003): Helminth parasites communities in two species of shorebirds (Charadrii) from Namibia. Comp. Parasitol., 70: 155 - 161 Cremonte, F., Digiani, M. C., Bala, L. O., NAvone, G. T. (2001): Tetrameres (Tetrameres) megaphasmidiata $\mathrm{n}$. sp. (Nematoda: Tetrameridae), a parasite of the two-banded plover, Charadrius falklandicus, and white-rumped sandpiper, Calidris fuscicollis, from Patagonia, Argentina. J. Parasitol., 87: 148 - 151

Digiani, M.C., CRemonte, F. (2001): New host and locality records for Tetrameres (Gynaecophila) spirospi- culum Pinto and Vincente, 1995 (Nematoda: Tetrameridae), with new morphological data. Mem. Inst. Oswaldo Cruz, Rio de Jainero, 96: 339 - 341

FERIANC, O. (1977): Birds of Slovakia 1. Veda, Publ. House SAS, Bratislava

HANZElOVÁ, V., MACKO, J.K., MACKOVÁ, A.: Anomotaenia alata and Anomotaenia barusi n. sp. (Cestoda: Dilepididae) from Charadrius dubius L. in Slovakia, with comments on other related Anomotaenia species. Acta Parasitol. (in press)

HovorkA, J. (1954): Helmintologická diagnostika. I. Laboratórna diagnostika helmintóz. Publ. House SAS Bratislava

Chabaud, A. G. (1952): Sur un Capillaria du vannean. Ann. Parasit. Hum. Com., I., 27: 400 - 406

Chabaud, A. G., Bain, O. (1994): The evolutionary expansion of the Spirurida. Int. J. Parasitol., 24: 1179 1201

JÖGIS, V. A. (1974): Nematodes from birds of the Kaliningrad district and Estonian SSR. Parasitologičeskij sbornik. Publ. House AN SSSR, Vol. 26: 81-114

MACKO, J. K., BIROVÁ, V. (1969): Epizootologische Bedeuntung der Forschung von Organophaenoten in einer Tiefebenenpopulation Heterakis gallinarum I. Biológia (Bratislava), 24: $617-622$

MACKO, J. K., BARUŠ, V. (1973): The finding of Victorocara guschanscoi (Nematoda, Schistorophidae) in Czechoslovakia. Folia Parasitol., 20: 381 - 382

Macko, J. K., BIRovÁ, V. (1976): Ein Beitrag zum Phänofond von Heterakis gallinarum II. Über die Bedeutung der Forschung der Artstruktur in der Helminthologie. Biológia (Bratislava), 31: 91 - 103

Macko, J. K., HanzelovÁ, V., MackovÁ, A. (2004): Platyhelmintes of three species of shorebirds (Charadriformes) in Slovak Republic. Helminthologia, 41: 151 - 159

MAWson, P. M. (1968): Nematodes from australian waders. Parasitology, 58: 277 - 305

MAYR, E. (1963): Animal species and evolution. The Belknap Press of Havard Univ., Cambridge

Mollhagen, T. R. (1976): A study of the systematics and hosts of the parasitic nematode genus Tetrameres (Habronematoidea: Tetrameridae). Ph.D.dissertation. Texas Tech. Univ. Lubbock, Texas

MORAVEC, F. (1982): Proposal of a new systematic arrangement of nematodes of the family Capillariidae. Folia Parasitol. (Praha), 29: $119-132$

Mozgovoy, A. A. (1953): Askaridaty of animals and man and the diseases caused by them. (Osnovy nematodologii). Publ. House ANSSSR, Moskva, Vol. 2, (in Russian)

ORTLEPP, R. J. (1964): Some helminths recovered from red- and yellow-billed hornbills from the Kruger National Park. Onderstepoort J. Vet. Res., 31: 39 - 52

Otero, C., And Lorenzo Hernandez, N. (1982): Lista de los helmintos de los vertebrados silvestres cubanos. Poeyana, 235: $1-57$

Pence, D. B., Mollhagen, T., Prestwood, A. K. (1975): Tetrameres (Tetrameres) tinamicola sp. n. from the crested tinamou, Eudromia elegans, with comments on the subge- 
nus Petrowimeres (Nematoda: Tetrameridae). J. Parasitol., 61: $825-829$

SERgeJeVA, T. P., BARUŠ, V. (1988): On Capillaria vanelli and Capillaria obtusiuscula (Capillariidae: Nematoda). Helminthologia, Košice, 25: 207 - 216

Skryabin, K. I., Sobolev, A.A. (1963): Spiruraty of animals and man and the diseases caused by them. (Part I.). Principles of nematodology, Vol. 11, Publ. House AN SSSR, Moscow (in Russian)

RECEIVED MAY 30, 2006
Skryabin, K. I., SoboleV, A.A., IVAŠKIN, V. M. (1965): Spiruraty of animals and man and the disease caused by them. Akuarioidei. (Part III.). Principles of nematodology, Vol. 14, Publ. House AN SSSR, Moscow (in Russian)

ŠPAKUlovÁ, M., MutAFOVA, T. (1987): Morphological and biological characteristics of heterakids (Heterakis gallinarum) from geographically distant regions. Helminthologia, 24: 183 - 191

ACCEPTED August 31, 2006 